\title{
Correction
}

\section{High lipoprotein (a), diabetes, and the extent of symptomatic intracranial atherosclerosis}

In the article "High lipoprotein (a), diabetes, and the extent of symptomatic intracranial atherosclerosis" (Neurology 2004;63:27-32) by Arenillas et al., there were errors in figures 1 and 2 . In figure 1, the final value for "Number of intracranial stenoses" on the horizontal axis should be $>2$. In figure 2, the first label on the horizontal axis should be "Lp (a) ( $\downarrow$ ) No DM." The corrected figures are shown below. The publisher apologizes for the errors.

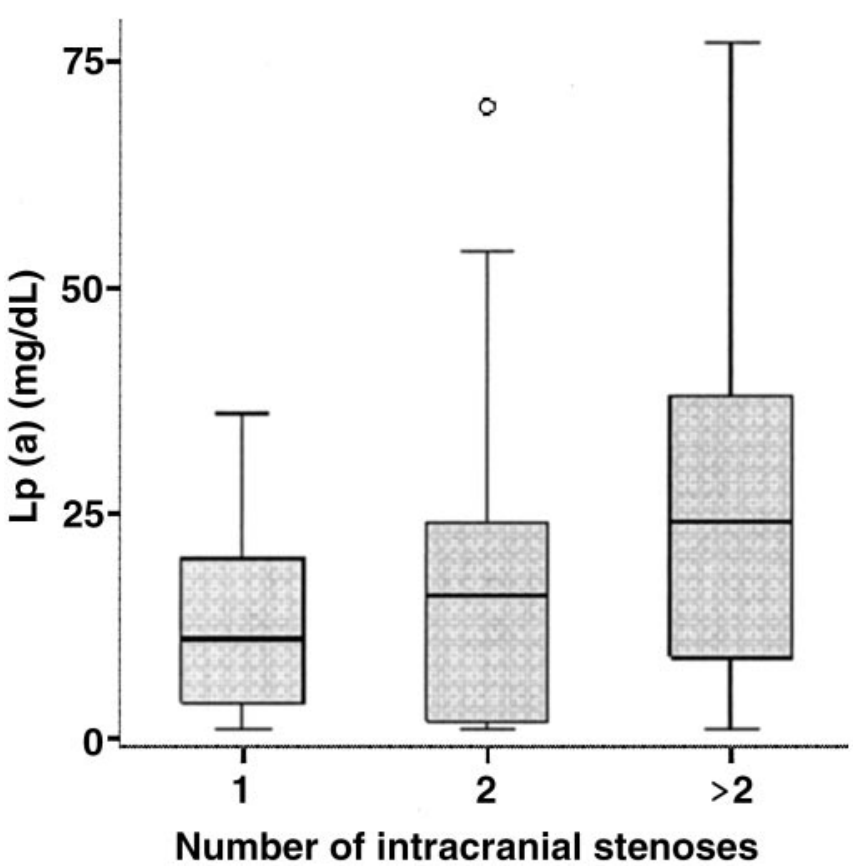

Figure 1. Median lipoprotein (a) (Lp[a]) serum level increases gradually with the number of intracranial stenoses $(\mathrm{p}=0.02$, Kruskal-Wallis test $)$.

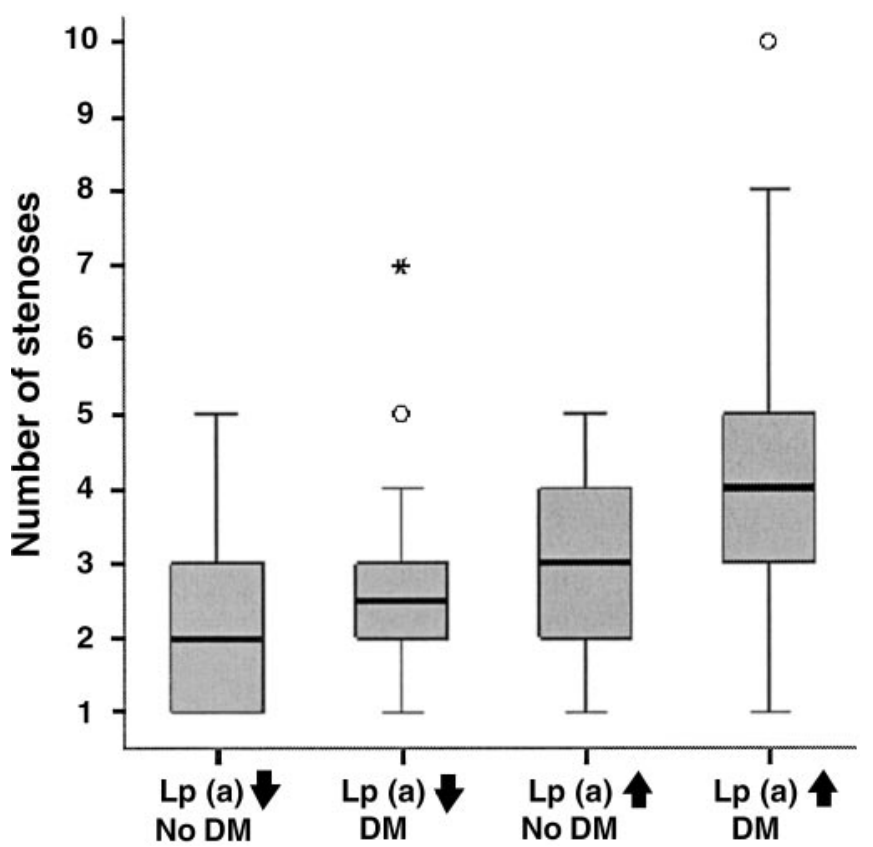

Figure 2. Potential interaction between lipoprotein (a) (Lp[a]) serum level and diabetes mellitus (DM), both independent markers of the extent of intracranial large-artery occlusive disease. The number of intracranial stenoses increases gradually in the different categories shown in the graph and reaches its maximum in diabetic patients with a high Lp(a) level ( $\mathrm{p}=0.001$, Kruskal-Wallis test). Arrows indicate low ( $\downarrow)$ and high ( $\uparrow)$ Lp (a) levels (see text); circles indicate outlier values and stars extreme values. 


\section{Neurology}

\section{High lipoprotein (a), diabetes, and the extent of symptomatic intracranial atherosclerosis \\ Neurology 2004;63;944 \\ DOI 10.1212/WNL.63.5.944}

This information is current as of September 13, 2004

\section{Updated Information \&}

Services

Permissions \& Licensing

Reprints including high resolution figures, can be found at: http://n.neurology.org/content/63/5/944.full

Information about reproducing this article in parts (figures,tables) or in its entirety can be found online at:

http://www.neurology.org/about/about_the_journal\#permissions

Information about ordering reprints can be found online:

http://n.neurology.org/subscribers/advertise

Neurology ${ }^{\circledR}$ is the official journal of the American Academy of Neurology. Published continuously since 1951, it is now a weekly with 48 issues per year. Copyright . All rights reserved. Print ISSN: 0028-3878. Online ISSN: 1526-632X.

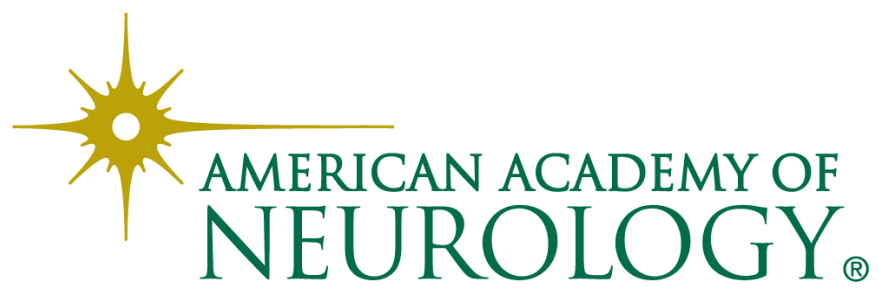

